Милена Д. Матић

Универзитет у Крагујевцу

Филолошко-уметнички факултет

Катедра за германистику

Мирјана Р. Обрадовић

Центар за проучавање језика

и књижевности
УДК: 811.163.41'243(075)

$371.3:: 811.163 .41 ' 243(075$

https://doi.org/10.18485/uzdanica.2020.17.2.5

Стручни рад

Примљен: 30. септембар 2020.

Прихваћен: 21. децембар 2020.

\title{
ИНТЕРКУЛТУРНИ ПРИСТУП У НАСТАВИ СРПСКОГ КАО СТРАНОГ ЈЕЗИКА: ЗНАЧАЈ ДИСКУРЗИВНЕ ЛИНГВОКУЛТУРОЛОГИЈЕ У ЕРИ ГЛОБАЛИЗАЦИЈЕ
}

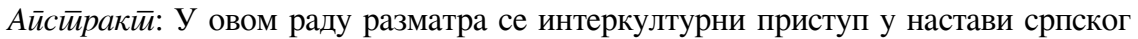
као страног језика, уз настојање да се осветли значај дискурзивне лингвокултурологије у ери глобализације. У наставном контексту страног језика анализирају се уџбеници који се користе у настави српског као страног језика у Србији и у иностранству. Показано је да доступни уџбеници културолошке садржаје претежно представљају фактографски, те да се не презентују негативни аспекти националне културе. Позитиван помак примећен је у уџбеницима за српски као страни који су објављени у иностранству. Могућност за побољшање интеркултурних уџбеника види се у окупљању матерњих и нематерњих говорника (српског) језика у оквирима ауторских тимова за израду уџбеника и у покушају доследнијег избора аутентичних садржаја који су културолошки обележени.

Кључне речи: интеркултурни приступ, лингвокултурологија, дискурзивна лингвокултурологија, глобализација, српски као страни језик, уџбеник.

\section{УВОДНА РАЗМАТРАҢА}

1. Посматрајући историју методологије наставе страног језика, можемо видети да се она кретала од граматичко-преводилачког ка комуникативном приступу. Комуникативни приступ учењу језика обликован је свешћу „о феноменолошкој разноликости језичких средстава, о когнитивним и културним видовима те разноликости, о различитим функцијама датог језика, о комуникацијском потенцијалу његових говорника, о диференцираним начинима његове употребе с обзиром на учеснике у комуникацији, на предмет и циљ комуникације, на ванјезични и ситуациони контекст" (Бугарски 1986: 150-151). Према томе, комуникација (на страном језику) је сложен процес, те је, између осталог, нужно да странац стекне одређена културолошка знања. У настави страних језика полази се од традиционалне, фактографски оријентисане лингвокултурологије, затим се у наставу уводи све већи број

milena.matic@filum.kg.ac.rs 
културолошких садржаја како би се развијале комуникативне способности код полазника курса, да би напослетку дошло до интегрисања интеркултурног и комуникативног приступа ради стицања знања, вештина и способности тумачења стране културе. Другим речима, „интеркултурни приступ помера тежиште с врло често неостваривог циља достизања компетенције матерњег говорника на циљ достизања интеркултурне комуникативне компетенције" (Корбет 2003: 2).

Интеркултурни приступ не значи нужно и увођење нових метода, већ је довољно проширивање постојећих и њихово усмеравање ка стварању интеркултурних говорника (Бајрам, Грибкова, Старки 2002: 7), који су у стању да критички процењују и препознају садржаје полазне и циљне културе, за разлику од ученика који имитирају матерњег говорника циљне културе, занемарујући сопствену.

Оливера Дурбаба сматра да термин иниееркулйурно није најподеснији и користи га искључиво због његове релевантне појмовне ширине и извесне уврежености у дидактичкој науци. Наиме, Дурбаба налази да се шароликост

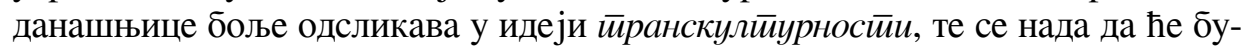
дући развој науке ићи у том правцу (Дурбаба 2016: 110).

2. Сам појам кулйуре изузетно је сложен и тешко се детерминише, јер се у литератури могу пронаћи бројне дефиниције и концепти. Наиме, „сви знају чиме се антропологија бави: бави се културом. Проблем је у томе што нико није сасвим сигуран у то шта је култура" (Герц 2012: 14). Различите дефиниције нуде већу флексибилност у дијалектичком приступу теми, што нам омогућава да прихватимо и видимо међусобну повезаност различитих погледа, у чему лежи и најбољи начин за разумевање сложености интеркултурне комуникације и сагледавање концепта културе из различитих перспектива. У овом раду ослонићемо се на Алтмајеров концепт културе (Алтмајер 2010) по коме се у стварности оријентишемо и заједнички свет тумачимо на основу образаца које смо научили током социјализације и које у дискурсима обично доживљавамо као општепознате и саморазумљиве. Култура је истовремено заједнички и научени образац веровања и схватања који су обострано разумљиви и широко доступни. Уколико су ови обрасци одређене стабилности, чувају се у културном памћењу групе, преносиви су и спознатљиви, можемо их сматрати културним интерпретативним обрасцима, а под културом подразумевати заједничку базу знања за дискурзивно тумачење стварности (Алтмајер 2007: 11).

На самом почетку примене културних метода у учењу страних језика, појам културе углавном се односио на садржаје високе културе, а не на свакодневицу (Дурбаба 2011: 48-49). Висока или Култура с великим $K$ (Китао 1991: 294) одувек је била заступљена у уџбеницима за учење језика, а поред тога може се савладати и на часовима књижевности, историје или неформалним учењем. Оно што недостаје да би студенти могли успешно комуницирати 
на страном језику, јесте култура са малим $\kappa$, односно актуелна, веродостојна, неуниформисана свакодневица старосно, полно, друштвено, идеолошки и расно различитих појединаца и група.

Аутори уџбеника и даље селектују грађу желећи да представе имагинарну просечну породицу средње класе, њихове вредности, ставове и начин живота. Дакле, уџбеници обухватају оно што је фреквентно, занемарујући маргинализоване феномене и негативне појаве. Такав начин представљања доводи до фолклоризације културних садржаја, унификације и хомогенизације. Улепшавањем стварности, реалност се фалсификује, па се отуда наглашава да треба избегавати формализовану наставу страних језика и инсистирање на свему што је стереотипно, анегдотско и чудно у датој цивилизацији (Вујовић 2004: 74). Поред тога, тако селектован садржај не подстиче и не захтева интелектуални напор у промени перспективе ученика, те не може бити подлога за истински интеркултурно оријентисану наставу. Међутим, у наставним материјалима за учење страног језика и даље преовлађују прикази комуникативних ситуација ослобођених замки културолошки изазваних конфликата, па је због тога од велике важности радити на утврђивању и потенцијално инцидентних ситуација за сваки појединачни језичко-културолошки пар и обрађивати их у настави (Дурбаба 2016: 159).

Термин линівокулйуролоїија у лингвистици се појављује у другој половини XX века, али се његов значај у настави страног језика знатно истиче тек почетком XXI века. Како у страној, тако ни у нашој литератури, терминологија још увек није устаљена, те се могу наћи разни појмови или описи

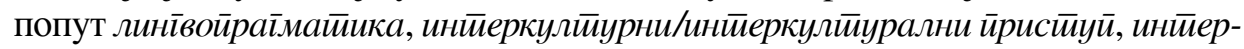

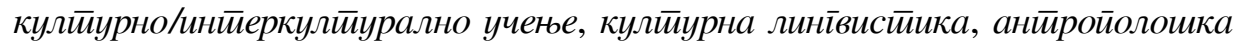

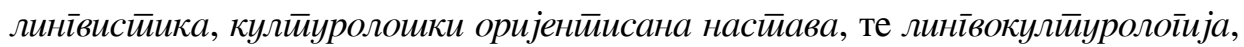
који се као најфреквентнији термин у већем броју словенских земаља користи у настави страних језика (в. Маслова 2001; Кириченко, Шамаєва 2008; Драгићевић 2011; Раичевић 2011; Дурбаба 2016; Барчот 2017; Кончаревић 2018).

Како су се циљеви и садржај наставе страног језика с временом мењали, неопходно је изнова сагледати и дефинисати и саму лингвокултурологију. Она се не може посматрати независно од учења језика, јер настаје само помоћу језика и у њему, тачније језичком употребом у дискурсима. Алтмајеров концепт дискурзивне лингвокултурологије инспирисан је Герцовим схватањем културе као мреже значења и Фукоовом анализом дискурса (Алтмајер 2010: 1408) и као такав знатно се разликује од традиционалне лингвокултурологије. Узимајући у обзир то да свет око себе тумачимо кроз одређене интерпретативне обрасце, дискурси као конструкти који регулишу људску интеракцију имају велики утицај на нашу интерпретацију света и наше деловање у њему. Људи који деле исте обрасце способни су да се међусобно разумеју и створе заједничку интерпретацију света. Може се рећи 
да дискурзивну лингвокултурологију у основи чине тематски дефинисани дискурси који се могу материјализовати у облику текстуалних корпуса (Алтмајер 2014: 32). Њихова обрада на часу страног језика не би требало да за циљ има учење реалија и прикупљање информација о страној култури, већ сензибилизацију ученика о културним обрасцима стране културе и освешћивање и испитивање властитих образаца.

Полазећи од чињенице да је интеркултурни приступ у учењу страних језика модел који предлаже Европска комисија и Унеско, те да је интегрисан у многе европске образовне системе, док је у Србији ово релативно нов модел ${ }^{1}$, у овом раду испитују се предности и недостаци у презентовању културолошких садржаја у уџбеницима за српски као страни језик, а уз то се предлажу и неки модели за унапређење уџбеника. Квалитативном методом анализира се заступљеност културолошких елемената у уџбеницима и разматрају се разлози (не)укључивања појединих сегмената културе чији се језик учи, те утицаји које то има на исход учења језика у глобализованом свету.

\section{1. ГЛОБАЛИЗАЦИЈА И ГЛОБАЛИСТИЧКИ УЏБЕНИЦИ}

У последњој деценији XX века у друштвеним наукама (в. Робертсон 1992; Гиденс 2003; Бек 2007) термин іллобализација успоставља се као појам за фундаменталне промене друштвеног, политичког и културног оквира у научном дискурсу. Са глобализацијом су и конвенционалне категорије попут земље, нације или културног идентитета постале упитне. Кодифициране норме, које изворни говорници узимају здраво за готово, све више се доводе у питање у савременом глобализованом свету. У питање се доводе и модернистички принципи у настави, те су научници забринути да глобализација уноси дубоке промене у наше начине размишљања, учења и сазнања, бојећи се да образовне институције нису кадре да се са њима носе (Крамш 2014: 297). Алтмајер сматра да образовне институције још увек нису сагледале епохалне промене и изазове које доноси глобализација. Концепти глобалног учења и глобалног образовања, о којима се расправља у различитим контекстима међународне сарадње још од прелазног миленијума, и даље нису пронашле свој пут у образовне институције (Алтмајер 2017: 18). Оно што је потребно нису приступи у погледу културног аспекта наставе страних језика, већ темељна промена парадигме, каква се већ дуже може уочити на теоријско-концептуалном нивоу културолошких студија (енгл. Cultural studies).

${ }^{1}$ Интеркултурна компетенција се тек 2017. званично појављује као једна од кључних компетенција у Општим стандардима постигнућа за крај основног образовања за страни језик (Службени йласник РС, бр. 88/2017). 
Међутим, у пракси тенденције ка стандардизацији и оријентисаност на компетенције прете да у потпуности елиминишу културолошки диференциране и дивергентне теме из уџбеника за учење страних језика. Како примећује Дурбаба, у глобалистичким уџбеницима какве конципирају велики интернационални издавачи долази до културолошке неутрализације, одстрањивања садржаја и тема које би могле бити непримерене у некој култури, па као такви нису погодни за културолошко-контрастивну обраду - губе на сазнајној вредности и мотивационом капацитету (Дурбаба 2016: 354-355).

Иако понекад делују недостижно, захтеви и изазови културне глобализације не смеју се избегавати, већ се мора активно радити на покушају да се тим захтевима одговори. Глобалистички процес који би у будућности комуникацију свео на једнојезичност значио би несхватање комплексности света и његово осиромашивање. Ипак, мера између инсистирања на различитости приликом увежбавања културолошки исправног понашања и игнорисања дивергентности тешко се проналази. „Први приступ се може екстремизовати до неке врсте културног расизма, а други проистиче из тумачења последица глобализације као културно нивелишућег процеса, те ово може бити и наговештај колапса читаве интеркултурне парадигме - пре него што је она истински и заживела" (Дурбаба 2016: 356).

\section{2. УЏБЕНИЦИ ЗА УЧЕЊЕ СРПСКОГ КАО СТРАНОГ ЈЕЗИКА}

\section{1. УЏБЕНИЦИ ЧИЈИ СУ АУТОРИ МАТЕРЫИ ГОВОРНИЦИ СРПСКОГ ЈЕЗИКА}

У домаћој литератури уочен је проблем осмишљене селекције лексике која је „основно средство за успостављање комуникације и језичко исказивање” (Крајишник 2011: 123). Наиме, из три уџбеника за почетни ниво учења српског језика ексцерпирано је чак 4203 појединачне лексеме, међутим само 378 лексема присутно је у сва три уџбеника (Исто: 124). Уколико је такво стање у погледу презентације лексике (за коју је, чини се, једноставније поставити критеријуме избора, те одредити лексички минимум²), онда се може претпоставити да је стање много сложеније у домену лингвокултуролошких сегмената српског језика будући да још не располажемо регистром таквих јединица (уп. Драгићевић 2011: 91)

Уколико сагледамо ситуацију на примерима уџбеника за српски као страни језик, видећемо да је фокус и даље на граматици, а да се култура

${ }^{2} \mathrm{O}$ критеријумима по којима се формира лексички минимум погледати у: Дражић 2008: $14-19$. 
презентује тек узгред, поготово на почетним нивоима, па се тако у уџбенику Научимо срйски 1 нигде експлицитно не говори о нашој храни, грађевинама, фестивалима (Спасић 2018: 390), при чему је један стих из Ршумовићеве песме „Деца су украс света” једини прецедентни текст пронађен у уџбенику. Уџбеник Научимо срйски 2 тематски више покрива ову област, али се све културолошки релевантне информације откривају тек у додатним текстовима (Николић 2016: 443).

С друге стране, аутори уџбеника Учимо срйски 2, у жељи да обухвате што већи број културолошких тема, неке од њих су обрадили само површно, кроз набрајање (Перишић Арсић 2018: 100). Иако се лексици дало доста простора кроз идиоме, загонетке и сленг, њихово присуство ограничава се на вежбе у којима се од ученика очекује да препознају и протумаче ове културолошки обојене изразе без њиховог претходног објашњења. Перишић Арсић не сматра посебно успелим ни покушај увођења елемената интеркултуралности кроз серију разговора Тамаре и Дана, који припадају различитим културама, јер у њима нема реалног сусрета и размене култура, те тиме не резултирају ни стимулативно ни аутентично (Перишић Арсић 2018: 101).

Уџбеник Срйски корак йо корак 1 намењен је говорницима енглеског језика и садржи сегменте посвећене српској култури и традицији. Међутим, исечци из културе и традиције увек су у функцији увођења нових речи или граматичких правила, при чему се уочава одсуство фотографија, питања која подстичу дискусију и додатних објашњења (Спасић 2018: 392).

Увођење прецедентних текстова је од кључног значаја јер они представљају добар пример везе између језика и културе. Иако се у уџбеницима за српски као страни језик налазе бројни прецедентни називи, обично изостаје употреба прецедентних текстова. Међутим, у уџбенику Срйски језик,

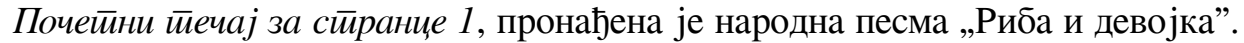
У истом уџбенику сазнајемо да су пршута, сир, кајмак, пасуљ, ћевапи, пљескавице, сарма и проја традиционална српска јела, а ракија типично српско пиће, да су кључне речи које описују нашу културу народно коло, слава, православна вера, кафана, земунице и салаш, али нема ничега из познатих српских филмова, слогана из актуелних реклама, нити стихова популарних песама. Примећује се да се и овде испољава тенденција ка стереотипизацији науштрб аутентичности.

Прецедентни текстови потпуно су изостали у уџбенику Serbian/Croatian for Foreigners (Николић 2016: 442), као и употреба лексике којом се означавају храна и пиће карактеристични за нашу традицију, при чему се могу наћи архаичне лингвокултуреме попут Југословена или омладинске радне акције. 


\section{2. УЏБЕНИЦИ ЧИЈИ СУ АУТОРИ НЕМАТЕРЬИ ГОВОРНИЦИ СРПСКОГ ЈЕЗИКА}

За разлику од уџбеника објављених у Србији, уџбеници за учење српског језика који су објављени у иностранству показују отворенији приступ према свим варијантама нашег језика, у складу са теоријама о полицентричности језика (Перишић Арсић 2018: 101). Такав је на пример уџбеник Sretan put италијанске издавачке куће Edizioni Goliardiche.

Посматрајући даље уџбенике за српски као страни језик који су објављени у нематичним земљама, наилазимо на анализу двају уџбеника Универзитета у Кракову: Priručnik za srpski kao strani jezik (2011) и Kultura živog jezika (2012) у којој К. Мијаљевић показује да аутори посебну пажњу посвећују методичком осмишљавању културолошких и друштевених прилика у Србији. Можемо видети да су наша земља и култура представљене као део Европе и света, при чему питања и задаци усмеравају студенте да без стереотипа разматрају културно специфичне информације о Србији. На средњем и напредном нивоу знања културолошка компетенција стиче се поређењем српске и матерње културе уз „проблемски и критички приступ садржајима, осветљавајући савремену стварност у Србији из различитих углова и усмеравајући полазнике да на објективан начин сагледавају сва питања" (Мијаљевић 2019: 166).

\subsection{1. Предлози за побољшање уџбенника}

На трагу новог приступа, на часу страног језика од ученика се очекује да науче да декодирају садржаје циљне културе и њене вредности како би их упоредили са полазном културом, а не да искључиво прикупљају информације о местима где се циљни језик говори или само увежбавају и усвајају вештине вербалне комуникације. Неопходно је додатно стимулисати високошколске институције, професионалне организације, а нарочито практичаре да се ангажују у конципирању акредитованих програма из области интеркултуралности (Петровић, Јокић 2016: 163).

Ваљало би размислити о томе да би се израда уџбеника за учење страног језика могла одвијати у сарадњи матерњег и нематерњег говорника, те да не би било рђаво посаветовати се са „странцем” и озбиљно размотрити мултикултурне групе аутора као једно од могућих решења за интеркултурне уџбенике (Перишић Арсић 2018: 103). Наиме, уочен је позитивни моменат у уџбеницима за српски као страни језик чији су аутори нематерњи говорници српског језика, што нас наводи да помислимо како би уџбеник конципиран из различитих ауторских перспектива могао добрим делом да отклони недостатке постојећих уџбеника. 
Независно од матерњег језика ауторског тима, треба тежити томе да будући уџбеници обухвате и оно што се сматра проблематичним или негативним у српском језику и култури. Предмет дискурзивне лингвокултурологије данас више нису земља и народ, већ дискурси који се воде на једном језику и обрасци интерпретације који се том приликом користе. Према томе, неопходно је превазићи когнитивно-фактографски приступ и презентовање информација у уџбеницима заменити аутентичним садржајима.

J. Редли сматра да би уџбенике требало додатно допунити фразеолошким изразима, пословицама и изрекама, чије познавање омогућава њихову правилну примену у свакодневној комуникацији, те колоквијалним и жаргонским изразима, који у потпуности изостају, након чега саветује обраду дијалога и говорних ситуација подложних комуникативним неспоразумима, јер би се на њима могле увежавати вештине којима би се такви конфликти спречили (Редли 2018: 90-91).

Поред аутентичних и новинских текстова који доприносе усвајању знања из савремене културне реалности, а која се потом могу лако поредити са полазном културом, саветује се и „директни контакт са циљном културом у виду размене ученика и студената, гостујућих предавања или контакт путем друштвених мрежа, како би се увежбала вештина интеракције” (Гаши 2019: 95). Сви аутори наглашавају да је неопходно мотивисати ученике на сарадњу. Како би се то постигло, Гаши предлаже технике и методе које смештају ученике у централни положај самог процеса, као што су тандемско учење, критичке дискусије, дијалози, драматизација и TBLT/TBLL ${ }^{3}$. Наведени методи подстичу развој интеркултурне компетенције јер подразумевају рад у пару и групама, рад на пројекту, употребу савремених технологија, „што је ученицима занимљиво, те остају дуже мотивисани у процесу усвајања, јер имају прилике да се креативно изразе” (Гаши 2019: 97).

Теорију језичких йејзажа можемо посматрати као још један могући приступ у преношењу културних садржаја, који има за циљ да натписи из свакодневног локалног окружења циљне културе постану наставни садржај (Кореик, Форноф 2020: 609). То могу бити улични знакови, имена предузећа, рекламни текстови и друго. Овај приступ омогућава занимљиве наставне пројекте који могу бити веома продуктивни, јер омогућавају да се учење доживи из нове перспективе (в. Бадштибнер Кицик 2018; Шидермајер 2018).

Један од значајнијих пројеката у ком се културне специфичности нашег подручја могу посматрати из угла будућих корисника самих приручника и који може да послужи ауторима уџбеника српског језика за странце јесте пројекат LabCom који је реализовао Центар за истраживање дидактике језика Универзитета у Венецији. Највећи допринос овог пројекта свакако је његова актуелност, будући да се сајт редовно ажурира: „Кључ разумевања

\footnotetext{
${ }^{3}$ Task-Based Language Teaching / Task-Based Language Learning
} 
овог пројекта лежи у његовој недовршености, како аутори не претендују да дају коначну, фосилизирану слику једне културе, јер њу чине појединци, па се овде ради само о назнакама које су у сталној провери кроз практичну употребу" (Перишић Арсић 2018: 98).

\section{ЗАКЉУЧАК}

Примећено је да у настави страних језика недостаје отворен дискурс о улози страног језика и културе коју један језик преноси у процесу глобализације. Како нас обавештавају аутори радова које смо овом приликом разматрали (Дурбаба 2016; Алтмајер 2017; Кореик, Форноф 2020; Крамш 2014; Гаши 2019), треба довести у питање застареле концепте лингвокултурологије, јер предмет учења страног језика нису чињенице, културеме, нити социјални односи, већ дискурси, културни обрасци који се користе у дискурсима и значења која дискурзивно произлазе на овој основи.

Узимајући у обзир коментаре које су досадашњи истраживачи изнели о уџбеницима за српски као страни језик, закључујемо следеће.

1) Уколико се у уџбеницима представљају културолошки садржаји, то се чини фактографски, стереотипно и увек у циљу стицања изразито позитивне слике о Србима и српској култури.

2) Изостаје дијалогизација и конфронтација аутентичних културолошких садржаја.

3) Прецедентни називи и текстови уводе се без прецизних критеријума и не доприносе унапређивању интеркултуралне компетенције.

Исход наставе страног језика не треба ограничити само на комуникативну компетенцију у свакодневним, контролисаним ситуацијама, већ треба мотивисати полазника курса да активно и одговорно учествује у дискурсима на циљном језику. Ослањајући се на Алтмајерову поставку о дискурзивној лингвокултурологији, налазимо да међусобно разумевање носилаца различитих језика треба да буде основа за заједничко тумачење света, где се однос према страној култури гради на постулатима емпатије кроз истовремено преиспитивање сопствених културних образаца. Циљ тако посматране лингвокултурологије, дискурзивне лингвокултурологије, заправо је увежбавање вештине дискурса, па закључујемо да је за израду уџбеника најпогоднији интеркултурни ауторски тим, односно повезивање матерњих и нематерњих говорника, који би на заједничкој основи, а ипак сваки са свог становишта, доприносили одабиру релевантних уџбеничких садржаја. 


\section{ИЗВОРИ}

Алановић и др. (2007): M. Alanović, I. Bjelaković, N. Bugarski, J. Dražić, M. Kurešević, J. Vojnović, Naučimo srpski 2, Let’s learn Serbian, Novi Sad: Filozofski fakultet: Dnevnik.

Бабић (2001): S. Babić, Serbian/Croatian for foreigners, book one, Београд: Задужбина Илије М. Коларца.

Бјелаковић, Војновић (2006): I. Bjelaković, J. Vojnović, Научимо срӣски. Let's learn Serbian 1, Novi Sad: Univerzitet u Novom Sadu.

Даниловић (2011): Mirjana Danilović, Step by step 1 / Корак ӣo корак 1, Beograd: Kornet.

Либер, Прпа (2011): K. Liber, S. Prpa, Priručnik za srpski kao strani jezik, Krakow: Wydawnictwo Uniwersytetu Jagiellonskiego.

Либер, Прпа (2012): K. Liber, S. Prpa, Kultura živog jezika, Krakow: Wydawnictwo Uniwersytetu Jagiellonskiego.

Милићевић Добромиров и др. (2006): Н. Милићевић Добромиров, љ. Ћук, Н. Радуловић, Учимо срӣски 2, Нови Сад: Азбукум.

Пуљезе (2008): G. Pugliese, Sretan put. Manuale della lingua croata, bosniaca, serba per italiani, Trieste: Edizioni Goliardiche.

Селимовић Момчиловић, Живанић (2011): M. Selimović-Momčilović, Lj. Živanić, Reč po reč - srpski jezik: početni tečaj za strance. Serbian elementary course for foreigners, Beograd: Institut za strane jezike.

\section{ЛИТЕРАТУРА}

Алтмајер (2007): C. Altmayer, Von der Landeskunde zur Kulturwissenschaft? Innovation oder Modetrend?, Germanistische Mitteilungen, 65/2007, 7-21.

Алтмајер (2010): C. Altmayer, Konzepte von Kultur im Kontext von Deutsch als Fremd- und Zweitsprache, Deutsch als Fremd- und Zweitsprache. Ein internationales Handbuch. 2. Halbband, Berlin/New York: De Gruyter Mouton, 1402-1413.

Алтмајер (2014): C. Altmayer, Zur Rolle der Literatur im Rahmen der Kulturstudien Deutsch als Fremdsprache, Literatur in Deutsch als Fremdsprache und internationaler Germanistik. Konzepte, Themen Forschungsperspektiven, Tübingen: Stauffenburg Verlag, 25-37.

Алтмајер (2017): C. Altmayer, Landeskunde im Globalisierungskontext: Wozu noch Kultur im DaF-Unterricht?, Kulturelles Lernen im DaF/DaZ-Unterricht, Paradigmenwechsel in der Landeskunde, 96, Göttingen: Universitätsverlag, 3-22.

Бадштибнер Кицик (2018): Historische Linguistic Landscapes im Film, Linguistic Landscape und Fremdsprachendidaktik, Frankfurt a.M.: Peter Lang (= Posener Beiträge zur Angewandten Linguistik 10), 235-271.

Бајрам, Грибкова, Старки (2002): М. Byram, B. Gribkova, H. Starkey, Developing the Intercultural Dimension in Language Teachin, A Practical Introductiong for Teachers, Strasbourg: Council of Europe, Language Policy Division.

Барчот (2017): B. Barčot, Lingvokulturologija i zoonimska frazeologija, Zagreb: Hrvatska sveučilišna naklada. 
Бек (2007): U. Beck, Einleitung, Generation Global. Ein Crashkurs, Frankfurt a.M.: Suhrkamp, 7-11.

Бугарски (1986): R. Bugarski, Jezik u kontekstu, Beograd: Čigoja štampa - XX vek.

Вујовић (2004): A. Vujović, Kratak istorijski pregled izučavanja strane civilizacije u okviru nastave stranog jezika, Pedagogija, 59/1: 68-79.

Гаши (2019): T. Gaši, Interkulturna kompetencija u nastavi stranih jezika - predlog za metode i tehnike u nastavnoj praksi, Živi jezici: časopis za strane jezike i književnosti, 39/1, Beograd: Filološki fakultet, 87-100.

Герц (2012): C. Geertz, Available Light: Anthropological Reflections on Philosophical Topics, Princeton: Princeton University Press.

Гиденс (2003): A. Giddens, Runaway world: How globalization is reshaping our lives, New York: Taylor \& Francis.

Драгићевић (2011): Р. Драгићевић, Лингвокултуролошки приступ у настави

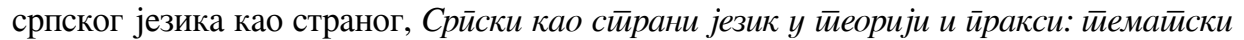
зборник раяова 2, Београд: Филолошки факултет, 81-93.

Дражић (2008): J. Dražić, Minimalne leksičke i gramatičke strukture u srpskom kao stranom jeziku, Novi Sad: Filozofski fakultet.

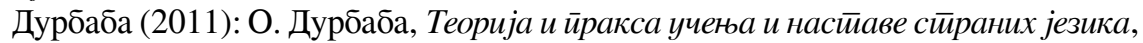
Београд: Завод за уџбенике.

Дурб์аба (2016): O. Durbaba, Kultura i nastava stranih jezika. Uvod u interkulturnu primenjenu lingvistiku, Beograd: Filološki fakultet.

Закон о основама система образовања и васпитања, Службени ілласник РC, бр. 88/2017(3), 27/2018(3), 27/2018(22), 10/2019(5), 6/2020(20), Београд: Министарство просвете, науке и технолошког развоја Р. Србије. Преузето 16. 9. 2020. са сајта https://www.pravno-informacioni-sistem.rs/SlGlasnikPortal/eli/rep/sgrs/skupstina/ zakon/2017/88/1/reg.

Кириченко, Шамаева (2008): Н. А. Кириченко, Ю. Ю. Шамаєва, The Image Constituent of the Emotional Concept Joy (Represented in Modern English Songs), Англійська мова та література 20, 62-73.

Китао (1991): K. Kitao, Teaching Culture in Foreign Language Instruction in the United States, Doshisha Studies in English, 52-53, 285-306.

Кончаревић (2018): K. Končarevic, Jezik i kultura - slavistička perspektiva, Beograd: Jasen.

Корбет (2003): J. Corbett, An Intercultural Approach to English Language Teaching, Languages for Intercultural Communication and Education 7, Clevedon - Buffalo - Toronto - Sydney: Multilingual Matters Ltd.

Кореик, Форноф (2020): U. Koreik, R. Fornoff, Landeskunde/Kulturstudien und kulturelles Lernen im Fach DaF/DaZ - Eine Bestandsaufnahme und kritische Positionierung, Zeitschrift für Interkulturellen Fremdsprachenunterricht, 25/1, 563-648.

Крајишник (2011): В. Крајишник, Лексички аспекти у српском као страном

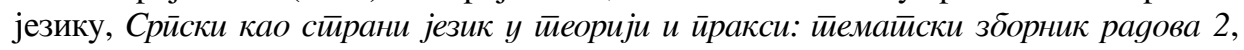
Београд: Филолошки факултет, 123-131.

Крамш (2014): C. Kramsch, Teaching Foreign Languages in an Era of Globalization: Introduction, The Modern Language Journal 98, 1, 296-311.

Маслова (2001): В. А. Маслова, Лингвокультурология, Москва: Издательский центр Академия. 
Мијаљевић (2019): К. Мијаљевић, Слика Србије у уџбеницима за српски као страни језик објављеним на Универзитету у Кракову, Зборник раgова Пеgайошкоі факулйейа, бр. 21, Ужице: Педагошки факултет у Ужицу, 157-170.

Николић (2016): Б. Николић, Лингвокултуролошки лексички слој у уџбеницима српског језика за странце, Слависииика, књ. ХХ, Београд: Славистичко друштво Сроије, 433-444.

Перишић Арсић (2018): O. Perišić Arsić, Različiti aspekti kulture u udžbenicima srpskog jezika kao stranog, Deveti međunarodni interdisciplinarni simpozijum Susret kultura, Novi Sad: Filozofski fakultet, 95-105.

Петровић, Јокић (2016): D. Petrović, T. Jokić, Interkulturalno obrazovanje u Srbiji: regulativni okvir, stanje i mogućnosti za razvoj, Beograd: Centar za obrazovne politike.

Раичевић (2011): В. Раичевић, Улога, статус и актуелни задаци лингвокултурологије, Слависииика XV , Београд: Славистичко друштво Србије, 258-266.

Редли (2018): J. Redli, Razvijanje interkulturne svesti u radu sa studentima srpskog jezika kao stranog, Deveti međunarodni interdisciplinarni simpozijum Susret kultura, Novi Sad: Filozofski fakultet, 83-93.

Робертсон (1992): R. Robertson, Globalization, Social Theory and Global Culture, London: Sage.

Спасић (2018): Н. Спасић, Аутентичност српске културе у дидактичким материјалима српског као страног језика за А ниво (лингвокултуролошки аспект), Брен-

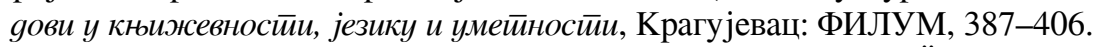

Шидермајер (2018): S. Schiedermair, Schrift in der Stadt. Öffentliche Sprachlandschaften als individuelle Lernlandschaften, Linguistic Landscape und Fremdsprachendidaktik, Berlin: Lang, 173-199.

\section{Milena D. Matić}

Universität zu Kragujevac

Fakultät für Philologie und Künste

Lehrstuhl für Germanistik

Mirjana R. Obradović

Zentrum für Sprach- und Literaturforschung

\section{INTERKULTURELLER ANSATZ IM UNTERRICHT DES SERBISCHEN ALS FREMDSPRACHE: DIE BEDEUTUNG DER DISKURSIVEN LANDESKUNDE IM ZEITALTER DER GLOBALISIERUNG}

Zusammenfassung: In dieser Arbeit wird der interkulturelle Ansatz im Fremdsprachunterricht erörtert und zugleich die Bedeutung der Landeskunde im Fach Serbisch als Fremdsprache im Zeitalter der Globalisierung zu betonen. Altmayers Konzept der diskursiven Landeskunde stellt die traditionelle und Fakten vermittelnde Landeskunde infrage, da der Gegenstand des Fremdsprachenlernens nicht die Fakten oder soziale Beziehungen sind, sondern Diskurse, kulturelle Muster, die in Diskursen verwendet werden, und Bedeutungen, 
die auf dieser Grundlage diskursiv entstehen. Deshalb sollte der Fremdsprachenunterricht nicht nur auf die Kommunikationskompetenz der Schüler in alltäglichen und kontrollierten Situationen beschränkt sein, sondern die Lernenden motivieren, aktiv und verantwortungsbewusst an Diskursen in der Zielsprache teilzunehmen. Das gegenseitige Verständnis von Sprechern verschiedener Sprachen sollte die Grundlage für eine gemeinsame Interpretation der Welt sein, in der die Einstellung zu fremden Kulturen auf den Postulaten der Empathie beruht, indem gleichzeitig die eigenen kulturellen Muster in Betracht gezogen werden. Das Ziel einer auf dieser Weise betrachtenden Landeskunde, einer diskursiven Landeskunde, würde darin besteht, die Fähigkeit des Diskurses zu üben. Im Rahmen unserer Arbeit werden Lehrbücher präsentiert, die heutzutage beim Unterrichten von Serbisch als Fremdsprache in Serbien und im Ausland verwendet werden. Die verfügbaren Lehrbücher stellen den kulturellen Inhalt meist sachlich dar und vermeiden negative Aspekte der nationalen Kultur. In Lehrbüchern für Serbisch als Fremdsprache, die im Ausland veröffentlicht sind jedoch positive Fortschritte in diesem Bereich festzustellen. Die Möglichkeit zur Vervollkommnung der Lehrbücher könnte daher in einem Autorenteam aus Muttersprachlern und Nicht-Muttersprachlern liegen, die in Zusammenarbeit, aber auch jeder aus seiner Sicht, relevante authentische Inhalte auswählen. In zukünftigen Arbeiten sollte näher erforscht werden, welche Kultursegmente sind den Lernenden aufgrund ihrer Muttersprache im Fremdsprachunterricht zu präsentieren. Solche Forschungen könnten dazu beitragen, sprachliche und kulturelle Inhalte in den Diskurs einzubeziehen und anstatt passiv kulturelle Inhalte, die als exotisch in den Unterricht eingeführt werden, zu übernehmen, wird der Lernende wirklich ein aktiver Teilnehmer an dem Dialog, der nicht nur zwischen dem Muttersprachler und dem Lernenden entsteht, sondern auch auf zwischen dem Muttersprachler und der ganzen Welt geführt werden könnte.

Schlüsselwörter: interkultureller Ansatz, Fremdsprachenunterricht, Serbisch als Fremdsprache, Landeskunde, Lehrbuch, diskusive Landeskunde, Globalisierung. 